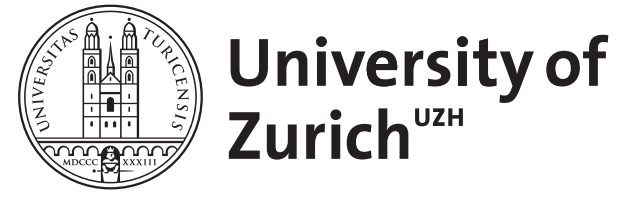

\title{
Orpheus and mousikê in Greek Tragedy
}

\author{
Semenzato, Camille
}

\begin{abstract}
Much as he is famous, Orpheus is only mentioned by name fourteen times in the Greek tragedies and tragic fragments that have survived the ravages of time. Furthermore he is never shown as a protagonist, but always evoked by a dramatic character as an example, a parallel, a peculiarity, or a fantasy. This legendary singer is mentioned every time, if not explicitly, at least implicitly, in conjunction with
\end{abstract}

DOI: https://doi.org/10.1515/tc-2016-0016

Posted at the Zurich Open Repository and Archive, University of Zurich

ZORA URL: https://doi.org/10.5167/uzh-171919

Journal Article

Published Version

Originally published at:

Semenzato, Camille (2016). Orpheus and mousikê in Greek Tragedy. Trends in Classics, 8(2):295-316.

DOI: https://doi.org/10.1515/tc-2016-0016 


\title{
Camille Semenzato* \\ Orpheus and mousikê in Greek Tragedy
}

DOI 10.1515/tc-2016-0016

\begin{abstract}
Much as he is famous, Orpheus is only mentioned by name fourteen times in the Greek tragedies and tragic fragments that have survived the ravages of time. Furthermore he is never shown as a protagonist, but always evoked by a dramatic character as an example, a parallel, a peculiarity, or a fantasy. This legendary singer is mentioned every time, if not explicitly, at least implicitly, in con-

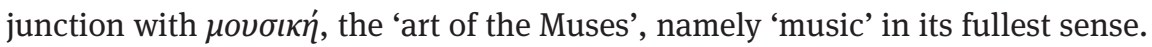
Each of these allusions recalls and highlights his prodigious and superhuman musical qualities and abilities.
\end{abstract}

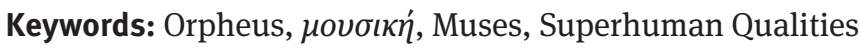

After two and a half millennia, Orpheus remains one of the most famous mythical figures from Greek antiquity. Our oldest literary source describes him as

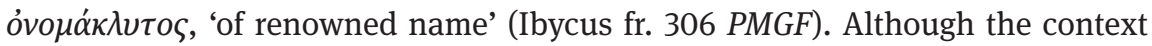
of this comment is now lost, it does show that Orpheus' reputation was already well established in the sixth century BCE. ${ }^{1}$ We know that in ancient times he was considered the greatest singer and poet, and credited with extraordinary qualities and abilities. What is more, many musical and literary works were attributed to him; these works in turn inspired numerous rituals and cults. Thus, over the centuries, followers of the practices and beliefs commonly clustered under the expression $\tau \dot{\alpha}$ 'O $\rho \iota \kappa \alpha^{2}$ claimed to be the keepers of Orpheus' legacy. This exceptional centuries-old resonance, principally because of the multiplicity of its intertwined factual and interpretative layers, complicates even further the scholar's task. Here are two extreme examples: first, the authors describing the turning points in Orpheus' life were not active before the first century BCE; ${ }^{3}$ and second,

1 On this Ibycus fragment and the context of the quote by Priscianus, see Riedweg 2004, 37; Ercoles 2009, 47.

2 See especially Graf 1987; Bernabé 2008a; Henrichs 2010, 92, as well as the various references noted in these publications.

3 Verg. G. 4.453-525; Ov. Met. 10.1-11.84.

*Corresponding author: Camille Semenzato, Zurich University, E-Mail: camille.semenzato@uzh.ch 
the Orphic movement is mainly known through the Neoplatonists, who sought to adjust Orpheus' alleged thoughts to those of Plato. ${ }^{4}$

Notwithstanding the layers, the trends, and the different time periods, Orpheus remains always the same. I shall argue in this paper that whatever the period, the context, the literary passage he figures in, his character suggests and reveals the same mysterious music. It is this music that, like the game of life and death, displays an amazing unity and coherence, despite the fact that it is highly varied, composed as it is of infinite rhythms, tensions, tones, melodies, and colours. And this happens ever since Orpheus first appears in tragic plays.

Given that Greek tragedies mostly date from the fifth century BCE, they are particularly helpful, in that they contain some of the oldest literary references to Orpheus. These versified, rhythmic, and melodic, hence poetic and musical, testimonia do not seek to identify, clarify or explain any cultural particularity, but rather they reveal heroes and events of Greek myths. Poets recount myths in many ways, each time in a different light, within varied contexts and circumstances, as well as bringing them to life time and time again. ${ }^{5}$ Another important aspect of tragic plays is that they were produced for special occasions and performed as part of a festival dedicated to the god Dionysus, who is linked to the artistic forces

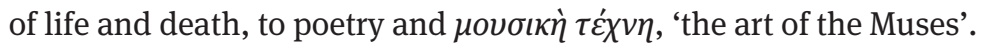

In Greek tragedy, Orpheus figures in Aeschylus, Euripides, Diogenes, and in the work of an unknown author. Our singer is never the main character in any of the surviving plays. A play by Aristias was named after him (TrGF 9 F5 Snell), but all that remains is the title. The same applies to Aeschylus' Bassarides: a plot-summary found in Eratosthenes' Catasterismi tells us that the play contained a version of Orpheus' demise, ${ }^{6}$ but only the third-century BCE scientist's words have survived without any further clarification. ${ }^{7}$

The evidence speaks for itself: in the entire surviving tragic corpus, Orpheus is only mentioned fourteen times; he is constantly referred to by a protagonist, as an example, a parallel, a peculiarity, or even a fantasy. He is always mentioned

\footnotetext{
4 For recent scholarship, see, for example, Albinus 2000, 101-111; Cosi 2000; Roessli 2000; Brisson 2005, 848-852; Edmonds 2013, 11-70.

5 See Burian 1997, 178-179.

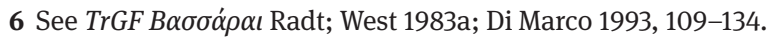

7 See Macías Otero 2008a, 1200-1202. She also notes (1185 n. 2) that the fragments TrGF Adesp. 8d, 291, and 597 Kannicht-Snell appear to point to other tragedies focusing on the myth of Orpheus.
} 
for his exceptional if not superhuman qualities; all of which, each in its own way,

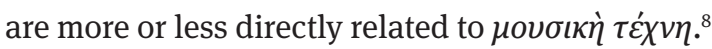

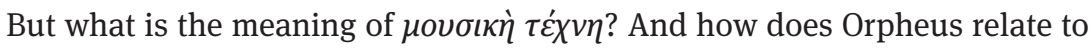

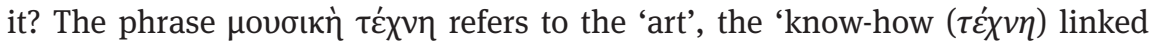

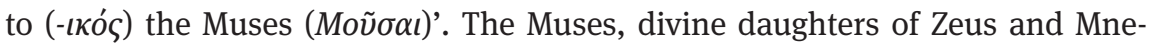
mosyne, ${ }^{9}$ gifted with the power of their father and the memory of their mother, are known to possess the knowledge of past, present, and future, ${ }^{10}$ which they can transmit musically. ${ }^{11}$ As such, they are able to inspire singers and poets, and through these 'vessels' they provide other mortals with a gateway to memory and destiny, as well as a proper musical balance in all things. They allow everyone to be distracted from pain, and to find their place in the world through music.

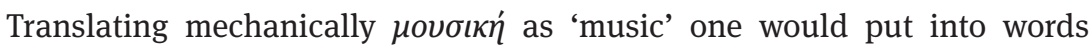
today's restricted conception of music, while at the same time missing out on what it really is, that is, a complex artistic system: voice, sung or recited, choral or monophonic song, poetry, instrumental music, rhythm, movement, and dance. All these put together constitute the extraordinary music of the Muses, who have the ability to express life's complex and striking nature in the most varied ways. One also misses out on its inspiring, divine, and mysterious dimension, which lies beyond the singer's technique and skills, not to mention its educational quality, which is fundamentally linked to this inspirational dimension. It is in this sense that, as spokesperson of the divine Muses, the singer is fundamentally a wise man, a mediator, a teacher, and ultimately, through his musical works, a guarantor of the right balance in people and things and of world harmony.

Orpheus is always described as a wise man, a mediator, and a teacher, not ordinary but indeed great and exceptional. The tradition is unanimous about his musical gift, which distinguishes him not only from common folk but also from every poet, mythical or historical, precisely because he maintains a privileged relationship, a high sensitivity, an intimacy with the musical powers he is able to express better than anyone else to such an extent that sometimes this can make the impossible possible.

8 Some identify Orpheus as the figure Lycurgus calls a $\mu$ ovбó $\mu \alpha v \tau \iota \varsigma$, a 'musical soothsayer' in

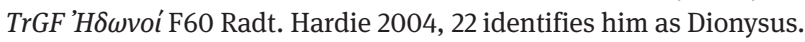

9 E. g. Hes. Th. 53-55.

10 Hes. Th. 38.

11 See principally Semenzato 2011 (doctoral thesis accessible at the University of Lausanne) with further references and 2017. 
Orpheus inherits his extraordinary gifts. He is said to be the son of a Muse, ${ }^{12}$ most often of Calliope, ${ }^{13}$ who for Hesiod (Theogony 79) is the greatest of all the Muses. It is very likely that Orpheus draws the beauty ( $\kappa \alpha \lambda o ́ \varsigma)$ of his voice (ó $\psi$ ) from her. Sometimes he is also known as the son of either Clio or Poly(hy)mnia, ${ }^{14}$ the first embodying good reputation ( $\kappa \lambda \varepsilon \dot{\delta} \circ$ ) and the latter multiplicity ( $\pi \circ \lambda v_{\zeta}$ ) of songs ( $\left.u^{\prime} \mu \nu o \varsigma\right)$. His father is said to be Apollo, the divine citharist, companion of the Muses, who is also an archer and a prophet; ${ }^{15}$ but for most people Orpheus is the son of Oeagrus, ${ }^{16}$ the Thracian river god. Thrace is not only Orpheus' motherland, but also the source of his music's power, breadth, and fluidity. ${ }^{17}$ Our singer, his kithara ${ }^{18}$ or the tablets attributed to him, ${ }^{19}$ are often defined as Thracian both in Greek tragedies and in other ancient texts. ${ }^{20}$ But apart from that relationship with Thrace, we do not find any mention of Orpheus' family connections in Greek tragedy. One passage in Rhesus (944) describes him as the cousin ( $\alpha \dot{\tau} \tau \alpha v \varepsilon \dot{\psi} \iota \varsigma$ ) of the play's eponymous hero, who is himself the son of a Muse; we can therefore infer that Orpheus' mother is also a Muse. Does this mean that the divine origin of Orpheus is of little interest to tragic poets? That they seek to humanize, to demystify the hero, as Macías Otero suggests? ${ }^{21}$ Probably not. The absence of evidence about his divine lineage can be attributed to his immense popularity. It is my contention that, as everyone seems to agree on the superhuman origin of his music, authors do not need to recall it. It is indeed unnecessary to repeat what everyone already knows - although this complicates the work of modern interpreters.

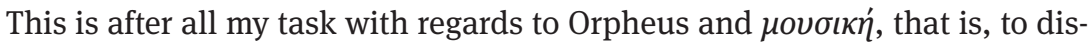
cover, unveil, and summon up the music, based on surviving textual snippets which can be analysed and interpreted thanks to all the knowledge that has sur-

12 E.g. Pl. R. 364e.

13 E. g. Apollod. FGrH 244 F146; A. R. 1.23-25; Schol. Hom. Il. 10.435.

14 For Clio: Schol. Hom. Il. 10.435. For Polyhymnia or Polymnia: A. R. 1.23-25.

15 E. g. Asclep.Tragil. FGrH 12 F6a-c. Athenaeus (14.632c) reinforces this view: 'the ancient wisdom of the Greeks appears to be very much addicted to music; and on this account they judged Apollo to be the most musical and the wisest of the gods, and Orpheus of the demigods'.

16 E. g. Pi. fr. 128c.11-12 Snell-Maehler; B. Dith. fr. ${ }^{\star \star 29 d .8 ; ~ S c h o l . ~ E u r . ~ R h e s . ~} 346$ (II 335.13 Schwartz).

17 The etymology of Orpheus is obscure. Although several ancient authors give their interpretation (see Bernabé 2008, 17 n. 6), the consensus today is that it is a Pre-Hellenic mythical name.

18 E. g. E. Hyps. fr. 752g.9 Kannicht.

19 E. Alc. 967.

20 To such an extent that, for example, at the turn of the Christian era, music in general originates in Thracia and Asia according to Strabo (10.3.17). Conon FGrH 26 F1.45.1 describes Thracia

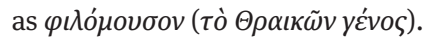

21 Macías Otero 2008b, 19-20. 
vived. Indeed, whilst this music is lost to us, it was common knowledge for the ancient Greeks.

In this paper I shall discuss fourteen passages which, I venture to hope, will gradually reveal an entire landscape through which we will understand better the figure of the legendary singer, the nature, scope, and limits of his extraordinary musical talent, as well as the special role these bestow upon him amidst common men. I shall also call into question and subsequently try to revise a number of modern misconceptions.

\section{Euripides, Bacchae 561-562}

In Bacchae's second stasimon, as the Chorus urges Dionysus to make his appearance in order to punish Pentheus for his excesses, everybody is wondering where the god might be. Several favourite places come to one's mind, including, among much else, the 'very wooded shelters of Olympus' (560-562). ${ }^{22}$ Carried away by the images, the Chorus suddenly glimpses in this divine locus not only Dionysus, but also Orpheus, ${ }^{23}$ 'who plays the kithara ( $\left.\kappa \iota \theta \alpha \rho i \zeta \omega \nu\right)$ ' (561-562). In doing so, through his music, Orpheus is able, says the Chorus, to ouvóycıv, literally 'lead together', i.e. 'unite, assemble' the phenomena that are the 'trees' ( $\delta \varepsilon \dot{\varepsilon} \delta \rho \varepsilon \alpha)$, the

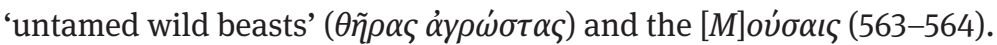

The trees, with their roots, trunks, branches, leaves, flowers, and fruit, represent the world of plants; the wild beasts, whose brutal, fierce, and bestial character is intensified by the epithet $\alpha y \rho \omega ́ \sigma \tau \eta \varsigma$, stand for the entire animal kingdom. The third word, Moṽ $\sigma \alpha$, is interpreted by most translators as the 'magical music', 'airs enchanteurs', or 'dolce melodia' of Orpheus' kithara. ${ }^{24}$ As the subject-object distinction between a person and his/her actions is modern, in addition to the fact that I always hear the word 'Muses' in the word 'music', I choose to capitalize the word, unlike most editors, in order to bring out not merely the notion of music as we know it today, but also the Muses themselves, those inspirational

22 Unless otherwise stated, Diggle's edition (OCT) is used for Euripides' text, and the translation is mine. For the discussion of etymological issues, I rely primarily on Chantraine 1999.

23 The recurrent link between Orpheus and Dionysus, Orphism and Dionysism, is often the object of intense study in our day. See Burkert 2006a; Jiménez San Cristóbal 2008b; Henrichs 2010, who takes stock of the current state of play. The link between Orpheus (and Dionysus) and the Muses is also recognised by critics, although dealt with marginaly, e. g. Hardie 2004.

24 See Dodds 1960, 146; Roux 1970, 150; Ieranò 2011, 41. 
and divine forces Orpheus the singer and kithara player knows and channels better than anyone else.

This passage from Bacchae demonstrates, in conjunction with the reference to Dionysus, Orpheus' awesome power and musical reach. By playing his kithara, the famous singer is able to assemble in a harmonious balance a variety of things: trees, wild animals, and musical deities. If he is capable of such feats, he is also gifted to influence men: the play's protagonist, Pentheus - which is what the Chorus wishes - or, more generally, anyone who hears or reads those lines; in fact, he can enter into another dimension, namely an impressive music that is beyond himself.

\section{Euripides, Hypsipyle fr. 752g.10 Kannicht}

A fragment from Hypsipyle describes the great power and reach of Orpheus' kithara. When the play's eponymous heroine complains about her situation and recalls her past, she remembers in particular that to move the ship of the Argonauts 'Orpheus' Thracian kithara clamoured an Asian elegy to the rhythm of i $\eta^{25}$

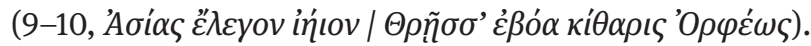

The accumulation of adjectives is suspicious and may suggest that a gloss was assimilated into the text. ${ }^{26}$ Furthermore, line 10 is often emended for reasons of metrical symmetry, which is why most editors write the name of Orpheus between brackets. ${ }^{27}$ Yet neither of these facts diminishes the impact of the scene: the kithara of the famous singer sings high and loud a song that affects the journey of the Argonauts. If the kithara does not do so directly, it certainly does so indirectly by stimulating the hearts and hands of the rowers through the rhythm originating from the sound of the strings.

Yet, according to the literary tradition, it is the aulos - not the kithara - that co-ordinates the rhythm of the rowers. ${ }^{28}$ Moreover, the term used by Hypsipyle for singing, $\dot{o}$ č`cyos, ${ }^{29}$ 'elegy', does not usually denote a lively melody, appropriate for rowers, but rather a 'plaintive' or 'mournful song, ${ }^{30}$ a rendition followed by

25 For the translation of the adjective ińı I follow Burkert (2006b): 'ieios-Takt'.

26 See Bond 1963, 71-72.

27 See Diggle 1995, 39-41.

28 E. g. Bélis 1999, 75-79.

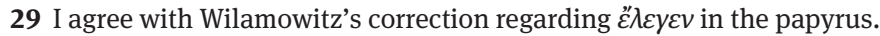

30 See also E. IT 146, 1091, Tr. 119. 
most scholars. ${ }^{31}$ As regards the epithet inı $ı$ - a divine epiklesis fashioned on the invocatory onomatopoeia in', which is linked to the god Paean and consequently to Apollo - it is usually translated in the same spirit, as 'mournful' or 'grievous' ${ }^{32}$

The context of the passage explains, however, these apparent paradoxes: the kithara usually emits a soft and tender sound, but here it does more than play, it cries out ('́ß㇒́ $\alpha$ ), screams, and clamours a resounding melody, a song so loud

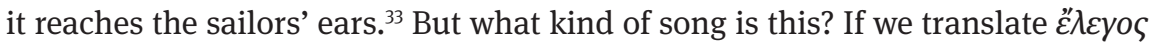
as 'complaint', it is a mournful song, the grievous character of which would be

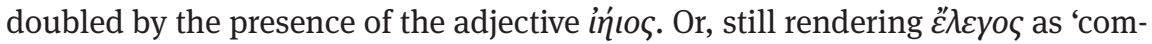
plaint', one might recognise in ińos the onomatopoeia in which, as similarly to what happens in paeans, punctuates the song, gives it its pace, and in this case conveys the motion of the boat. Both cases might be seen as symbolic of Hypsipyle's mood, sad and lonely. Another interpretation may be the following: for Kannicht, the kithara makes resound 'a hymn of thanks for their landfall'. ${ }^{34}$ An elegy may be a symposium-related exhortation, ${ }^{35}$ depending on the circumstances, just as the paean is either an apotropaic prayer or a celebration and a song of thanksgiving. ${ }^{36}$ In the next line the participle $\mu \varepsilon \lambda \pi о \mu \varepsilon \dot{v} \alpha$, which is associated with Orpheus' kithara, buttresses this suggestion. Mć $\lambda \varepsilon \varepsilon \sigma \theta \alpha \iota$ is often translated as 'to sing'. The verb refers to a collection of songs and dances performed rhythmically, none of which amounts to a sad complaint. It should be a happy song, vigorous, and energetic, ${ }^{37}$ which Hypsipyle hears and yearns for. The Asian character of the elegy reinforces this interpretation: it bears the mark of an exotic music, ${ }^{38}$ new and at first incomprehensible to the ears of our heroine, at the same time denoting in an ambivalent fashion both the boat's progression and her own feelings.

Like Orpheus' connection with Dionysus, the Thracian or even Asian origin of his kithara seems - by metonymy - to endow the singer with an amazing origin and power. Indeed, Orpheus is able to lead and guide the rowers, the oars, the

31 E. g. Collard/Cropp 2008, 271 (= Collard et al. 2004, 193): 'a mournful Asian plaint'; Jouan/ Van Looy 2002, 182: 'l'élégie asiatique', who nonetheless choose not to translate the adjective. 32 A similar meaning of this adjective is found in E. Ph. 1036-1037 and El. 1211.

33 Bo $\eta^{\prime}$ is sometimes used to describe the sound of the lyre, as well as the aulos, E. g. in Pi. P.

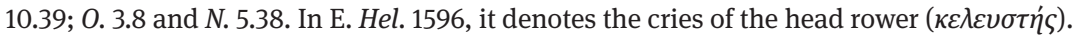

34 Quoted by Collard/Cropp 2008, 271.

35 Bowie 1986.

36 E. g. Rutherford 2001, 3-10.

37 See also at the end of a verse in a fragment of Euripides' Erechteus (fr. 65.5-6 Austin) the

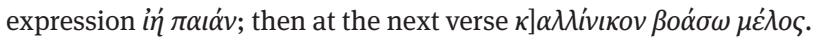

38 Collard et al. 2004, 234 describe it as 'exotic and elaborate'. 
boat itself, and the mood of a wide variety of protagonists. With his kithara, played on the musical mode of the Muse Melpomene, ${ }^{39}$ he gives an energetic pace to the oars and leads the boat's movement, as well as the feelings of the human characters. This rhythm and direction turn out to be extremely useful not only for the Argonauts' expedition but also for any voyage, progress, and advancement on life's path, whether this involves something inorganic, organic, human or divine.

\section{Euripides, Medea 543}

In the context of the expedition of the Argonauts, Jason praises the music of Orpheus. He is about to abandon Medea in order to take a royal bride in Corinth, but he fails to understand why the mother of his children is not grateful for everything she has gained ever since they married. In Greece, where justice and law prevail over barbaric force, though she is an alien, she is known and admired for her wisdom. Had she remained in Colchis, no one would have talked about her. Jason then adds that he would be willing to renounce all the gold in his house and even refuse the prospect of 'singing a more beautiful song than

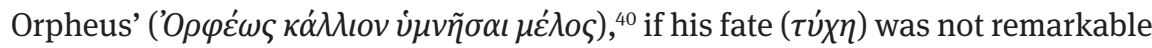

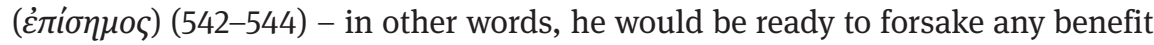
accruing from his favourable destiny.

For Jason it is more important to have a destiny marked with a sign (غं $\pi i^{-}$ $\sigma \eta \mu о \varsigma)$, which makes men stand out in the crowd, enjoy a high reputation, and survive in the memories of their fellowmen, than to possess what ordinary men covet most of all: gold, that is to say, material goods, land, wealth, which seem to offer all one may desire. Furthermore, he would even be willing to renounce the flaterring prospect of singing better than Orpheus - whose singing is defined here by the two widely used terms $\mu \varepsilon \dot{\lambda} \varsigma_{\varsigma}$ and $\dot{v} \mu \nu \varepsilon \tilde{\imath} v-,^{41}$ clearly an impossible feat, especially since Jason is never described as a musician, nor known to have any musical talent.

This reference to Orpheus is often interpreted as a form of irony on the part of Jason, especially taking into consideration the singer's famous loyalty and devotion to Eurydice. ${ }^{42}$ The audience could therefore 'compare and contrast the conduct of

39 See also Hardie 2012, 157-168 and 178-180.

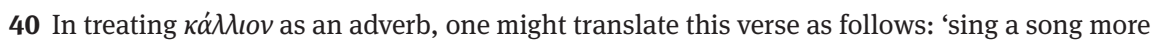
beautifully than Orpheus' - which is in the end the same thing.

41 See below E. Alc. 357 on Orpheus' $\mu$ ćlos.

42 E. g. Mastronarde 2002, 262. 
Jason and Orpheus towards their respective wives' ${ }^{43}$ Alongside Orpheus' nature as a model and a teacher, this passage can be seen as another laudation of his singing, the musical appeal of which is compared to the material appeal of gold. By attempting to show that his new hope can even surpass that of a semi-divine singer Jason is in fact trying to strengthen his point and lay bare Medea's error in judgment.

\section{TrGF Adesp. F129.6 Snell-Kannicht}

The comparison between gold and Orpheus' singing is also found in an anonymous tragic fragment quoted by Diodorus (37.30.2). The historian cites those lines to illustrate the pernicious power of gold, the appeal of which drives humans to excesses and finally causes misfortune. After a description of gold as 'the strongest of all things' because 'it charms all things', it is then compared to the power of Orpheus. Indeed, while 'trees and unintelligent kinds of wild beasts followed

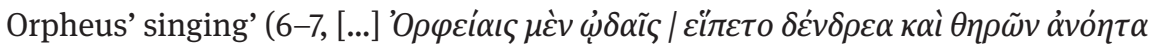

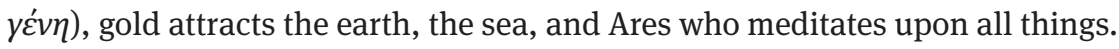

The author values so much the power of gold that he describes it as subjecting the entire world, even the sea and Ares, in the sense that all men are prepared to do anything - go to war, fight, play a part in perfidious intrigues - to get hold of that precious metal. In comparison, Orpheus' persuasiveness seems less powerful, because of Ares' ability to meditate on all things $(\pi \alpha \mu-\mu \eta \dot{\sigma} \sigma \omega \rho)$ which

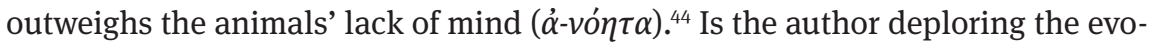
lution of things, that is, how warring and intelligent beings overpower pure and simple nature? It seems hard to believe that we have here an ode to gold. Be that as it may, the author evokes Orpheus' immense power: to bring along, to lead, and to guide phenomena which at first are not susceptible to music.

\section{Euripides, Iphigenia at Aulis 1211}

Iphigenia is also aware of the immense power of music. When she is about to be sacrificed at Aulis, she tries to bend her father's will by invoking Orpheus. She

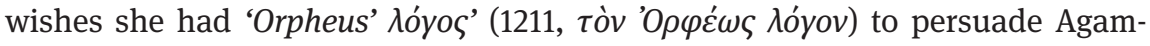

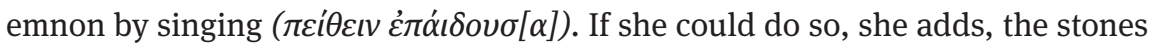

43 Mezzabotta 1994, 47-48, who also refers to a number of earlier interpretations.

44 The same adjective for $\mu о \tilde{\rho} \rho \alpha$ is found in Lyc. 490; Orph. fr. 47. 


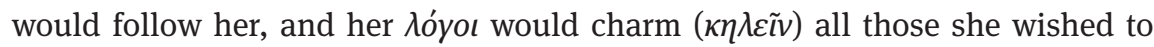
charm (1212-1213). Her fantasy is, however, illusory: she only has her tears, which fail to convince anyone.

As Iphigenia does not wish to possess Orpheus' singing or kithara but his

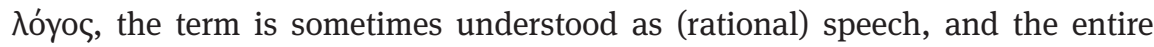
passage is linked to the rhetorical works of contemporary sophists, for whom Orpheus would be a model. ${ }^{45}$ However, in doing so, we overlook the pre-rational

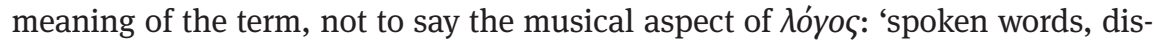
course' or, better still, 'an assortment of chosen words'. Far from wishing a logical, rational, and persuasive discourse, like that of a philosopher, Iphigenia dreams of a strictly musical discourse. Only well chosen, nuanced, melodic, that is, poetic and musical words can charm, enchant, and move the world as a whole. ${ }^{46}$

\section{Aeschylus, Agamemnon 1629}

Similarly, when Aegisthus mentions Orpheus' abilities, he distinguishes the language of the singer from that of the Chorus of the Argive old men. Hostile to the new king, they are belittled and accused of being annoying and arrogant: their $\gamma \lambda \tilde{\omega} \sigma \sigma \alpha$ - meaning both the 'organ' of speech and 'language' in general - contrasts ( $\varepsilon v \alpha v \tau i \alpha v)$ greatly with his. Aegisthus uses the same word and verb ( $\left.{ }^{\prime} y \varepsilon v v\right)$ to describe both Orpheus and the Chorus, but in each case he has a different action

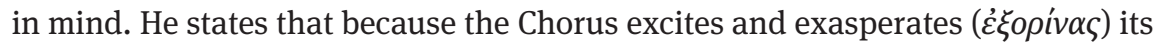
audience with foolish barkings ( and forced ( $\kappa \alpha \tau \eta \theta \varepsilon i \varsigma)$ by him (1629-1632). ${ }^{47}$ Just like a master would train his stubborn dog, Aegisthus will quickly discipline the Chorus for their foolish comments. The contrast is obvious: Orpheus ‘by sound, led all with joy’ $(1630,[. ..] \tilde{\eta} y \varepsilon$

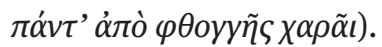

I suggest, alongside Fraenkel, ${ }^{48}$ that this passage reveals how the Greeks would place emphasis on the impropriety of certain comments or the rudeness of certain people by contrasting them with Orpheus' extraordinarily pertinent, elevated, and jovial words.

45 Macías Otero 2008b, 82-85 notes the musical aspect in Orpheus' rhetorical skills. For Orpheus as a precursor of the sophists, see Segal 1995, 292, 297, and 300-301; Molina Moreno 2008, 45-46.

46 See also Bernabé 2008a, 29.

47 I quote the Greek text from West's edition (Teubner).

48 Fraenkel 1950, 773. 
Everyone also agrees that Orpheus is a great leader; in fact, he possesses a $\varphi \theta o y y \eta$ ', mostly translated as 'a voice', although the term means more broadly a 'sound', a 'noise', the 'overall sound' of a phenomenon, person or thing ${ }^{49}-$ in this case his mouth and/or his kithara - which allows him to direct, guide, and lead all things. This reinforces my interpretation of the previous passages: Orpheus is singled out for his ability to assemble, lead, and bring along all things ( $\pi \alpha \dot{v} \tau \alpha)$ with the same enthusiasm, the same vigour, and the same music. So much so that no one can resist the delight, movement, and emotion, which he bestows on everything around him. Unlike the Chorus who, according to Aegisthus, bark out foolish words, Orpheus offers a promise of happiness: he provides a gateway to joy, pleasure, and great rejoicing. This is called $\chi \alpha \rho \alpha$ in Greek, an

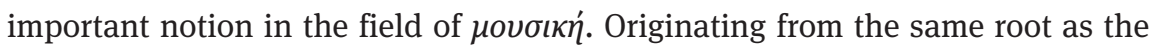

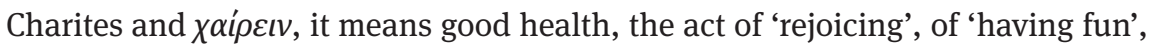
of 'being filled', 'la puissance même de la vie envisagée dans ce qui en constitue l'excellence'. ${ }^{50}$ Thus Aegisthus' mention of Orpheus implies that by listening and following the musician one is given a harmonious and joyful entry to all phenomena, including the gods.

\section{Euripides, Hypsipyle fr. 759a.1619 Kannicht}

If Orpheus is a musician with exceptional abilities and qualities, capable of ensuring everyone's balance and joy, what is his exact role? A passage in Hypsipyle gives us some answers that tie into my preceding comments.

One of the two sons Jason had with Hypsipyle tells us that after the death of his father, who had taken them away, still infants, from Lesbos and their mother, Orpheus had taken care of him and his brother. The renowned singer brought them (" $y \alpha y$ ' - as the guide we know he is) to a protected place of his own in Thrace (1619). There he teaches ( $\delta \iota \delta \alpha \sigma \kappa \varepsilon \tau \alpha \iota)$ one of them the 'Muse of the Asian kithara'

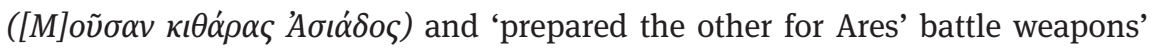

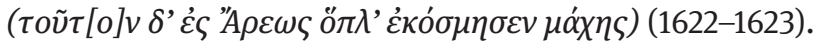

The role of Orpheus here is clear: he is the tutor of both children. ${ }^{51}$ What he teaches them is, however, very different: he initiates Euneos into music and Thoas into weaponry. The fact that he shares out his musical knowledge comes as

49 See also Aesch. Ag. 325, where the $\varphi \theta 0 y y \alpha i$ of the vanquished and that of the victors are also distinguishable one from the other.

50 Saintillan 1996, 320.

51 Because of this special educational relationship between Orpheus and Hypsipyle's sons, the 
no surprise, but it is difficult to understand how Orpheus the musician may also be knowledgeable about military practices.

The musical education is explicitly expressed by the verb $\delta\llcorner\delta \alpha \sigma \kappa \varepsilon \iota v$ and the name Moṽ $\sigma \alpha$. Muse is called 'of the Asian kithara' in the genitive which is in my view subjective - the Muse belongs to the kithara as the divine inspiration within the instrument (as objective); the kithara lets the Muse express herself and, by metonymy, the music she embodies. The instrument is thus the symbol of the divinity. Moreover, not unlike the elegy heard from Orpheus' kithara on the ship of the Argonauts, this kithara is also of Asian origin. Perhaps the Athenian public would have understood this as a reference to contemporary fashion, ${ }^{52}$ or to a particular location in Asia Minor (e.g. Lesbos, Lydia) where the kithara is said to have been invented. ${ }^{53}$ More importantly, the repeated references to Orpheus as having foreign, exotic, oriental roots, thus being Asian, as renowned and important as he might be in Greece, reminds one of Dionysus, with whom he often appears and in whose honour tragedies are performed.$^{54}$ Following Bernabé I suggest that this foreign, barbarian origin ${ }^{55}$ is the root of the incomprehensible (non-rational) and thus mysterious component of Orphic music.

The other facet of Orpheus' teaching differs from the first; and this becomes

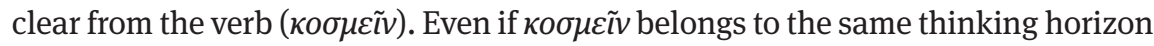
as $\delta \iota \delta \alpha ́ \sigma \kappa \varepsilon \iota v$, it denotes neither teaching nor tutoring. In Homer, the verb means to 'order' properly the troops, to 'arrange' them 'in' battle 'order'. ${ }^{56}$ What is more, it has gradually taken on another meaning: to 'adorn, decorate' and even 'honour' something properly. It is used this way, for example, by Euripides, when a fully armed Eteocles meets with the Mycenaean army (Ph. 861). ${ }^{57}$ This goes to show that Orpheus acts differently towards each brother: he teaches Euneos, tutors him, brings him from a state of ignorance to a state of knowledge, so that his pupil -

link between the singer and Dionysus is also strengthened: Hypsipyle is indeed, through her father Thoas, the granddaughter of the god (see Burkert 2006b).

52 Burkert 2006b, 115.

53 Cassio 2000, 107-108 with references to ancient sources.

54 See also Cassio 2000, 109-110. For the reference to the Athenian family of the Euneids, priests of Dionysos Melpomenos, see mainly Cassio 2000; Burkert 2006b. On Dionysos Melpomenos, see Hardie 2012, especially 163-169.

55 Bernabé 2008a, 29: 'Recuérdese que la palabra griega "bárbaro”, $\beta \alpha ́ \alpha \beta \alpha \rho o \varsigma$, no es sino la transposición imitativa del lenguaje incomprensible'.

56 E. g. Hom. Il. 2.554; Od. 9.157.

57 See for example the fact of adorning oneself with clothes (E. HF 333), to crown oneself (IA 760) or to honour properly someone (Heracl. 568). 
as Brillante notes ${ }^{58}$ - finally takes part in the music-learning process; ${ }^{59}$ but Thoas only receives an inclination, a sense of order, an idea of military finesse. If we take a closer look, however, коб $\mu \varepsilon \tilde{v} v$ is related to both weapons and music. The verb has

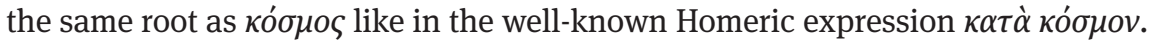
It refers to an attitude, a kind of behaviour, even adequate singing, well-ordered, harmonious, and balanced. It alludes to the good order of the world. ${ }^{60}$ Like Demodocus, ${ }^{61}$ a good singer not only narrates the events in a proper order, but also

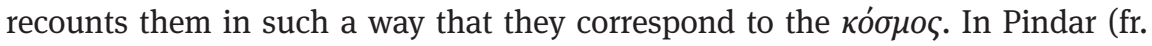
31 Maehler), the Muses themselves are called upon to bring order to all the great works accomplished by Zeus. Although the expression is never used by Euripides, it does help to link the meanings of the two verbs. However, the verbs are in differ-

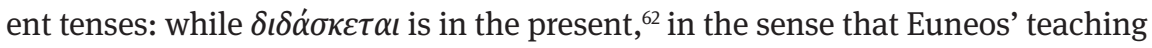
happens over time, or at least until he utters these words, દ́кó $\mu \eta \sigma \varepsilon v$ is in the aorist, which seems to imply that Thoas was prepared to using the weapons just the once. Regarding the weapons, one can note that, in a manner similar to the kithara, they are also linked to a god - yet again through the use of the genitive, which can be taken as both subjective and objective. This time of course is not a Muse but Ares, the god of war, with whom Orpheus is also connected..$^{63}$

Much as the boys share the same tutor, each one has his education and his god. The power of Orpheus' music here reveals a dual capacity to transform, to harmonise the world both with kithara-music and weapons. ${ }^{64}$ The challenge is basically identical: to promote the best possible balance and the greatest joy between the world's different elements not only in a soft or harmonious manner but also in a violent one, if necessary. As such, Orpheus' music seems increasingly complex and encompassing. Not only is it sonorous, beautiful, engaging, and entertaining; not only is it able to convey moods, as well as uniting, moving, and guiding all things, but it also carries a whole physical dimension and power that, depending on circumstances, can be gentle, entertaining, violent, and dangerous all at once.

58 Brillante 2009, 23 n. 13.

59 Just like for example the infant who learns how to speak and listen to what he does not understand initially (E. Supp. 914-915).

60 For all the Homeric examples, see Elmer 2010.

61 Hom. Od. 8.489.

62 On $\delta ı \delta \alpha ́ \sigma \kappa \varepsilon \tau \alpha \iota$ in the middle voice to be understood as active, see Bond 1963, 134.

63 For a connection between the Muses and Ares, see, for instance, Archil. fr. 1 West.

64 See Napoleon who engages in war just like he does with music: 'J'aime le pouvoir, moi, mais c'est en artiste que je l'aime ... Je l'aime comme un musicien qui aime son violon; je l'aime pour en tirer des sons, des accords, des harmonies', quoted by Taine 1884, 396 n. 2. 


\section{Euripides, Cyclops 646}

One of the Chorus leader's statements in Cyclops supports my interpretive approach. Whilst Odysseus is about to blind the monster, he says that he knows

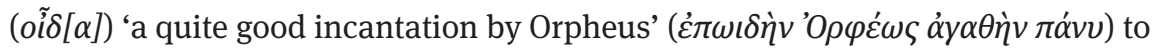
ensure that the brand may burn Cyclops' eye on its own (646-648).

It is quite likely that the Chorus leader - just like the rest of the Chorus of satyrs in this play - is fearful and cowardly, and seeks a way out to avoid taking action, ${ }^{65}$ at the same time never forgetting to make the audience laugh with his choice of words. ${ }^{66}$ However, he does confirm that Orpheus is able to intervene physically in the world through his singing; and this he is able to do beyond the limits of human reason.

The Chorus chooses to describe Orpheus' singing with the term $\varepsilon \pi \omega \delta \dot{\eta}$ which shares the same root as $\alpha \circ \delta \delta$ ' - the latter literally meaning a 'song' sung 'about or against' someone or something, and more generally, an 'incantation', which is by definition magical. ${ }^{67}$ Based on my exploration, the passage takes on a very clear meaning. Because of his non-Greek origin, Orpheus and his music have something that is not only complex and ambiguous but also surprising, mysterious, and magical. It is only by magic that a brand can plant itself ( $\alpha \dot{\tau} \tau o ́ \mu \alpha \tau o v$ in Greek) into an eye.

But what is magic? As 'the art or practice of using charms, spells, rituals to attempt to produce supernatural effects or control events in nature', defined thus in dictionaries or the 'posibilidad de dominar las leyes de la naturaleza y de doblegarlas a la propria voluntad', as Bernabé suggests, ${ }^{68}$ it is in fact very close to the ambiguous power of music. Especially since this incantation, which has the effect of burning Cyclops' eye, ${ }^{69}$ is described as quite a good one - not in a moral sense, but in a structural sense, meaning that it is worth something, in other words that it is effective. Therefore, despite the passage's hilarity, Orpheus' musical power is tangible again: a magical power to assemble, move, and influence everything.

65 See Ussher 1978, 158-159: 'The satyrs' hope is that persuasion will take the place of forceful physical action'.

66 See Bernabé 1998, 165; Martín Hernández 2006, 250.

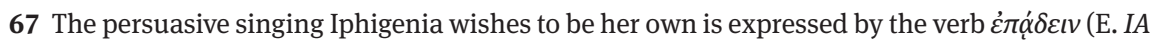

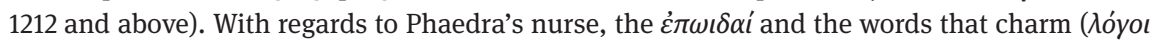

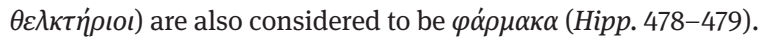

68 Bernabé 1998, 162.

69 Faraone 2008, 136 links this passage to the last sentences in the magical incantations written in hexameters in a number of papyri. See also Martín Hernández 2006, 251-257. 


\section{Euripides, Hippolytus 953}

Still reeling from Phaedra's suicide and the accusation she brought against Hippolytus, Theseus levels three charges against his son: boasting, practicing veg-

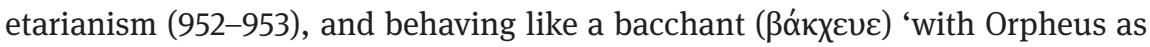

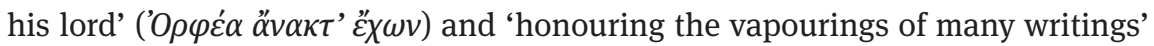

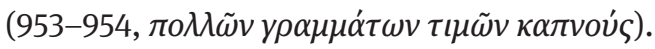

These lines have often been commented upon. Given the mention of vegetarianism and the presence of Orpheus' name, some critics wonder whether Hippolytus is an Orphic follower, as most followers of Orphism are vegetarians. Others question the validity of Theseus' charges, ${ }^{70}$ that is, whether he does not trump up these accusations. ${ }^{71}$ Some also wonder about the verb $\beta \alpha \kappa \chi \varepsilon v \varepsilon \varepsilon v$ which is associated with Dionysus, the bacchants, and for that reason all Dionysian initiates. Some, however, believe that the verb must be interpreted broadly, in a neutral way, as a general expression of an excited behaviour, a form of madness, ${ }^{72}$ a particular way of living. ${ }^{73}$ Regarding the nature of the $y \rho \alpha \dot{\alpha} \mu \alpha \alpha \tau \alpha$, the tendency is to interpret it as a contemporary criticism by a largely oral society positioning itself against the emergence of writing: ${ }^{74}$ and to consider $y \rho \alpha \dot{\mu} \mu \alpha \tau \alpha$ as the first explicit religious books, 'as a constitutive element of a person's religious identity', ${ }^{75}$ associated without further formalities with Orpheus himself. Although there is much evidence about the written works attributed to Orpheus the musician, ${ }^{76}$ it is impossible to know whether they are really the ones criticised in this passage.

Together with Zieske, ${ }^{77}$ I believe that the king is so angry that he expresses all the blame, all the hatred coursing through his mind, whether the blame is founded or not. He speaks of people who follow an odd diet, who follow Orpheus and therefore believe in superior forces, in the power of music, who behave wildly, like the bacchants, and who read books that contain nothing serious, clear, and constructive but only obscure truths, which are in this sense like smoke, that is to say nebulous. Taking a closer look, however, far from devaluing Orpheus - who

70 E. g. Méridier 1928; Henrichs 2003, 216; Scodel 2011, 81.

71 E. g. Barrett 1964, 342; Halleran 1995, 231; Zieske 2012, 24 and n. 2 with further references.

72 E. g. Linforth 1941, 56, who describes it as a 'crazy and irrational conduct'.

73 E. g. Jiménez San Cristóbal 2009, 50-51. For an in-depth discussion of the meaning of $\beta \alpha \dot{k} \chi \propto \varsigma$ and its derivatives, especially in Hippolytus, see Di Marco 1993, 104-109.

74 This view is especially based on Pl. R. 364e; see also Macías Otero 2008b, 95-96.

75 Henrichs 2003, 212.

76 E. g. Bernabé 2002; Henrichs 2003; Santamaría Álvarez 2008, 72-78; Edmonds 2013, 96-124. 77 Zieske 2012, 25-26. 
is shown to be a lord, a protector of bacchanalian festivals and other musical productions - the passage is far more critical of Theseus. ${ }^{78}$

\section{Diogenes 88 TrGF F7.10 Snell}

A fragment attributed to the tragic poet Diogenes of Sinope speaks of the grave dangers of focusing solely on music. This comes from a character who regrets

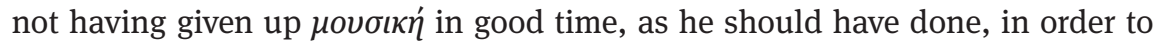

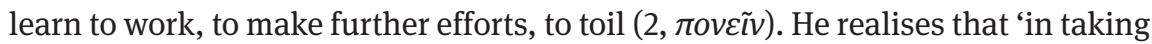

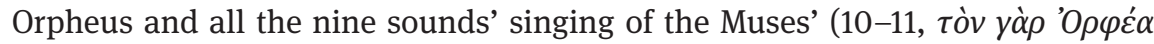

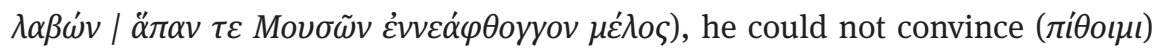
his belly, which rather needs a ßíos, a 'means of living', the required 'resources' (12).

If this fragment really belongs to Diogenes of Sinope, the most famous representative of the cynical school of philosophy, it is not surprising that he mocks Orpheus and the Muses' music, since based on his own philosophical position he denies every sacred thing, and therefore understandably the Orphic belief. ${ }^{79}$ Yet, beyond this cynical critique, these lines are to a certain extent instructive. They remind us of the already acknowledged link between Orpheus and the nine Muses - through, for example, the common use of the typical terms $\varphi \theta$ óyyos/

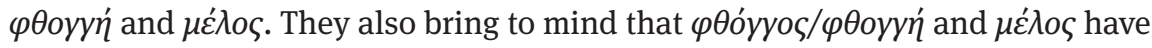
an effect, a persuasive function, a transformative role on men and all things. However, within a certain limit, duly recorded by Diogenes, in order to survive, the human stomach will not be satiated with songs and music but first and foremost by earthly nourishment. ${ }^{80}$ Orpheus' song is not the beginning and end of all things. Woe to anyone who indulges in Orpheus' music without measure: he might lose himself and die of hunger. It is all a matter of striking a balance between music and work, pleasure and pain, spiritual and earthly nourishment.

78 Contrary to traditional views (for a general presentation of Theseus, see Calame 1990; Mills 1997), I do not see Theseus as a role-model. Rather, Theseus seems to be here indirectly criticised for his pre-idealist understanding of things - that is, his refusal of musical enthusiasm.

79 D.L. 6.2.39; Bernabé 1998, 166.

80 Before becoming a singer, a poet or anything else, man is only a belly. See Hes. Th. 26. 


\section{Euripides, Alcestis 968}

Some ancient evidence shows that Orpheus' music was not only influential in words but also in writing. ${ }^{81}$ In Euripides' Alcestis the Chorus asserts the omnipotence of ávóyкn, 'necessity', which is more powerful than Orpheus' music and

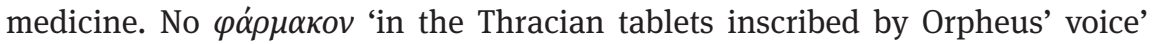

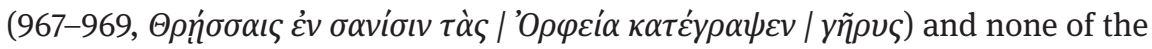
many $\varphi \dot{\alpha} \rho \mu \alpha \kappa \alpha$ that Phoebus gave the Asclepiadae for the use of mortals can alter destiny.

Unlike Hypsipyle's privileged children, who received a personalised education, apparently anyone could have access to the so-called 'Thracian tablets' ${ }^{82}$ These tablets are not Thracian because they were produced in that region, or because of the wood they are made of (the term $\sigma \alpha v i$ ' refers primarily to a 'plank'), ${ }^{83}$ but because they belong, by metonymy, to the Thracian singer himself - as well as symbolising the exotic and mysterious character of his music. Surprising as it may seem, it is his $\gamma \tilde{\eta} \rho v \varsigma$, 'voice' - the resonance of which is praised here ${ }^{84}-$ which inscribed the words on the tablets, a content of great value and great significance, to put it briefly, sacred. ${ }^{85}$

But which text is this? The Chorus reveals it: Orpheus' voice inscribed $\varphi \alpha \dot{\rho} \mu \alpha \kappa \alpha$, 'remedies' on the tablets. Not simple songs or poems, but words which, when pronounced, have a certain effect, can help, heal, and even save - such as

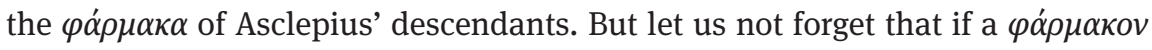
is primarily a 'remedy', it may also become a 'poison'. Like the dual education discussed above and music in general, the word highlights the dual nature, both beneficial and dangerous, of all things, a nature always marked by a tension between health and sickness, joy and sorrow, life and death. ${ }^{86}$ Everything is finally a matter of balance which Orpheus' music teaches like no other. Indeed, his songs, not unlike the remedies of the Asclepiadae, ${ }^{87}$ are defined by this

81 On Orpheus as an author, see n. 76 above and generally Bernabé 2002.

82 According to Bernabé 2002, 75, it is quite possible that Euripides' public was aware of such tablets. See also Roessli 2000, 21 who compares these tablets to the bone lamellae found in Olbia graves.

83 See the two occurrences of the word in Euripides: the plank placed in such a way so as to allow one to embark on a boat (Hel. 1556) and the door of a house (Or. 1221).

84 Musical resonance, like when Hermes plays his kithara (h.Merc. 4.426).

85 See Graf 1987, 94-95.

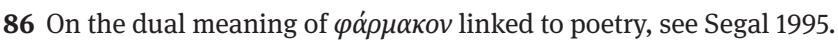

87 At the beginning of the play (121-130), the Chorus laments the disappearance of Asclepius who, before being struck with lightning, could raise the dead. 
amazing ambiguity. They stand between the power to go beyond the status of a mere mortal and this same power that vanishes in death. To put it in another way: medicine, ${ }^{88}$ just like music, can give men certain resources that are beyond their grasp, superhuman resources, which tend towards the divine, the immortal, but without ever reaching it. Every being is indeed determined by something still more powerful: $\dot{\alpha} v \dot{\alpha} \gamma \kappa \eta$, fate against which we can do nothing. ${ }^{89}$

Unlike Jourdan, ${ }^{90}$ I argue that the Chorus, far from criticising the musical power of Orpheus, questioning or even denying its effectiveness, draws attention to the possibility that music offers to capture and to go beyond human limits. But this step beyond, just like medicine, still remains subject to fate and thus fails to overcome the inescapable demise of all terrestrial phenomena.

\section{Euripides, Alcestis 357}

Alcestis is about to die, and Admetus says that if he had Orpheus' 'voice' ( $y \lambda \tilde{\omega} \sigma \sigma \alpha)$ and 'singing' ( $\mu \dot{\lambda} \lambda \circ \varsigma)$, to 'charm' ( $\kappa \eta \lambda \dot{\gamma} \sigma \alpha \nu \tau \alpha)$ Persephone and Hades, the rulers of the kingdom of the dead, he would descend to the underworld in search of Alcestis. And neither Hades' dog nor Charon would hold him back before he brought his wife back to the light (357-362).

Following the passage from Hippolytus this is the second most interpreted passage about 'Orphic doctrines' in Euripides. It evokes what one knows best about Orpheus, namely his mysterious descent to the land of the dead in order to bring his wife back to life. There is one major discrepancy, however. Orpheus' adventure ends in failure. ${ }^{91}$ It is widely known that Orpheus turns around too soon, and Eurydice is irrevocably swallowed up by the world of shadows. By contrast, in Alcestis, there is a sudden opportunity - fantasy of Admetus - to succeed in coming back from the dead. ${ }^{22}$ This is, however, a particularly problematic return, an impossible one, except in a world of magic or fantasy.

88 In Plin. HN 20.32; 28.34; 28.43 and Gal. De antid. 14.144 Kühn, for instance, Orpheus is seen as the author of medical books containing folk medicine and magic.

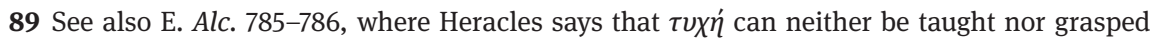
with $\tau \dot{\chi} \chi v \eta$.

90 Jourdan 2008, 9-10.

91 See Verg. G. 4.453-525; Ov. Met. 10.1-11.84.

92 See also Segal 1995, 300. For a different opinion, see the various references in Macías Otero 2008b, 47-48, and more generally, Heath 1994. 
One thing is certain that these lines once again highlight the superhuman nature of Orpheus' $y \lambda \tilde{\omega} \sigma \sigma \alpha$ and $\mu \varepsilon \dot{\lambda}{ }^{\circ}$, both symbols of his musical power. Through his voice and singing, Orpheus can charm ( $\kappa \eta \lambda \varepsilon \tilde{v})$ ) even the gods of the underworld. The chosen verb recalls the incantation mentioned by the Chorus leader in Cyclops: it is magic, the overpowering superhuman means that one would have to employ in order to deal with the underworld; it is musical magic, the secrets of which Orpheus apparently knows better than anyone else. Orpheus once again emerges as a guide and even as an exceptional guide, capable of leading men not only from ignorance to knowledge, from darkness to light, from sadness to joy, but also leading men to the shores of the impossible, namely from death to life.

Evidently, Admetus does not possess this power, but he yearns for it, fantasizes and dreams about it, so that his wife may continue to live. All in all, his wish is purely rhetorical, considering that he could have prevented Alcestis from passing away by accepting to die himself.

\section{3 [Euripides], Rhesus 943}

The way Orpheus is portrayed in Rhesus will help us conclude this overview. In a very short passage, the Muse describes the nature of Orpheus' mysterious enchanting and didactic powers. The goddess knows that Athena had her share of responsibility in the death of her son. She speaks of three elements which should have kept Athena from helping Odysseus to kill Rhesus. One of them relates to Orpheus. According to the Muse, Orpheus, introduced as Rhesus' cousin and therefore also as a son of a Muse, 'showed the torches of the unutterable myster-

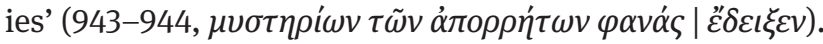

The verb $\delta \varepsilon \iota \kappa v u ́ v \alpha \iota$ means to 'show, present, indicate, demonstrate, reveal', and in this particular context is often interpreted as a technical term, that is, to set up a cult. ${ }^{93}$ However, one should focus on the first meaning of the verb, which is perfectly attuned to Orpheus' educational role. According to the Muse, Orpheus has revealed torches. A revelation that is all the more interesting because the

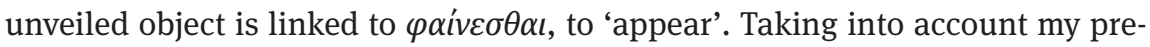
vious suggestions, not only does $\varphi \alpha v \eta$ mean a torch's full light, but also a torch

93 E. g. Plichon 2001, 12 'inventer et enseigner'; Markantonatos 2004, 30: 'introduce'; Liapis 2012, 320: 'establish'. 
appearing from out of the dark. ${ }^{94}$ By pondering further on this action, one realises that though it was at first glance quite innocuous, it is in fact most instructive. The torches that Orpheus lit and brandished are indeed related - only implicitly - to the light emerging from the darkness, and therefore to the mysterious cycle of day and night, the seasons in general, and finally life from death. This cycle is celebrated in the mysteries. ${ }^{95}$ Can these mysteries be identified? In view of the Muse's arguments, most scholars argue that they refer to the mysteries of Eleusis, which were considered to be the mysteries par excellence in Greek antiquity. ${ }^{96}$ I recognise here mysteries of life and death in general. ${ }^{97}$ However, nothing encourages me to do so with certainty, especially as these mysteries were described as $\alpha$ đó $\rho \rho \tau \alpha$, 'unutterable', though they were revealed by Orpheus. Is this not contradictory? 'Aлó $\rho \eta \tau o \varsigma$, which literally means 'what is forbidden, forbidden to say', - like its counterpart ä $\rho \rho \eta \tau, \varsigma$, 'which cannot be said, that one cannot speak of, unsayable', may bring to mind the secrecy imposed on initiates of the so-called mystery ceremonies. ${ }^{98}$ Is the famous singer defying therefore something that is prohibited? But this is not the import of this passage - in other words that once again Orpheus' merits are duly praised. One must agree

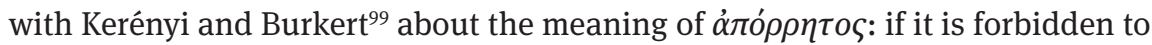
explain the mysteries, it is simply because they are impossible to explain. Far from being a real prohibition, the initiates' silence comes rather from the inability to describe clearly, that is to say, logically, with words, the obscure mysteries defining life. Orpheus is beyond the reach of common mortals through the excellence of his singing and music; for his language, his voice, and his logic are of musical obedience, go beyond human limits, touch the superhuman, allow him

94 Thus $\varphi \alpha v \eta$ ' is often translated as a 'procession', during which torches are brandished (see E.

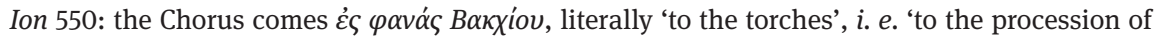
Bacchios', held in Delphi).

95 For Linforth 1941, 63 and Liapis 2012, 320 the torches are a metonymy for the mysteries themselves.

96 E. g. Graf 1974, 2 n. 7; 22-39 and other ancient sources apart from Rhesus; Markantonatos 2004, 31; Liapis 2012, 320; Fries 2014, 462. For further suggestions (the small mysteries of Agra; mysteries that are lost; mysteries in general), see Plichon 2001, 13-14 and her list of references.

97 See also Semenzato (forthcoming).

98 See principally h.Cer. 476-479.

99 Kerényi 1945, 19: 'Das Geheimgehaltene im griechischen Kult war sicherlich allen, die im Umkreis des betreffenden Kultortes wohnten, bekannt, es war aber ein Nicht-Auszusprechendes. [...] Erst nachher machen ausdrückliche Verbote das Arreton zu Aporreton'; Burkert 2011, 413: 'Die Geheimhaltung war radikal, wobei es nur offen blieb, ob "das Heilige” in diesen Fällen „verboten“, apórrheton, oder schlechthin „unsagbar“, árreton, sei’. 
to bring to light - a dappled light that emerges from obscurity - the inexpressible mysteries of life. ${ }^{100}$

\section{4 [Euripides], Rhesus 966}

It is in this sense that I also seek to interpret the second passage from Rhesus that refers to Orpheus. Continuing her monologue, the Muse comes to pray Persephone to grant her a favour: to let go, to release ( $\alpha v \varepsilon \tilde{v} v \alpha$ ), to allow Rhesus' $\psi v \chi \eta^{\prime}$ to

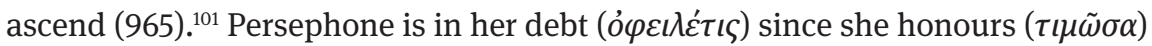

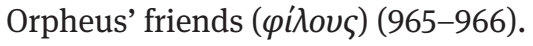

After evoking Orpheus' association with the mysteries, the Muse pursues with his link to Persephone. This link is as important as the one he shares with Apollo, Dionysus, the Muses, Ares, and all other deities we have previously encountered. Persephone is indebted to the singer's friends, to those he loves, ${ }^{102}$ because of the implied family ties between the Muse and Rhesus. How does this come to pass? The term ó $\varphi \varepsilon \iota \lambda \varepsilon ́ \tau \iota \zeta$ is an hapax. ${ }^{103}$ However, we understand that what links the singer to the mistress of the underworld is strong enough to allow Rhesus' $\psi v \chi \eta$ to ascend from the shadows to the light. Most commentators understand this connection not as a reference to Orpheus' musical abilities that enable him to go down to Hades to recover his wife but, more generally, as an allusion to his role as a revealer of mysteries, ${ }^{104}$ a mystagogue ${ }^{105}$ and even a shaman. ${ }^{106}$

In accordance with what we have seen so far, it is this mysterious music (echoing the game of life and death) which lends Orpheus his impressive qualities and amazing gifts, including, among much else, the power to reveal the darkest mysteries of life.

100 On the link between the Muses and the mysteries, see Hardie 2004, who notes the similar position of the words Moṽ $\alpha \iota$ and $\mu \nu \sigma \tau \eta \rho i \omega v$ in the line (12).

101 For an interpretation of this expression with reference to the rest of the passage, see Plichon 2001, 14-19; Liapis 2007, 394-406.

102 It should be noted that Admetus is not one of those friends.

103 See Fries 2014, 470.

104 E. g. Liapis 2012, 324; Fries 2014, 470.

105 Borgeaud 1991, 54.

106 E. g. West 1983b, 4-7; Fiore 1993. 
Much as he is famous, Orpheus is only mentioned by name fourteen times in the surviving tragic plays and fragments. Furthermore, he is never the protagonist but always evoked by a dramatic character in order to promote a certain example, make a comparison, pay tribute to someone, or indulge in a fantasy. Each time,

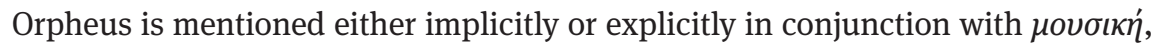
the 'art of the Muses, music' in its fullest sense. Each of these allusions both recalls and highlights his prodigious, superhuman musical qualities and abilities.

When a character evokes Orpheus, it is always to point out the extraordinary power the Muses grant him in comparison to feeble ordinary human abilities. If the human side of his music consists of singing, kithara-playing, poetry, and writing, his divine nature stems from the amazing musical forces he is able to wield. Thus, despite the wide range of ancient sources, Orpheus remains always the same: the prominent human agent of the Muses. ${ }^{107}$ He reveals in an admirable way their mysterious music, their singular truth, which, like the sacred game of life and death, is obviously varied, made out of infinite tonalities, rhythms, and variations; but underneath this impressive diversity there lies an amazing unity and coherence.

As an exceptional musician and singer, Orpheus has more than one string to his bow: he is able to resonate, assemble, unite, harmonise, lead, push forward, charm, enchant, and convince any of the world's phenomena, whether inorganic or organic, plants, animals, humans or gods. With a single motion, always advancing with and for joy, but also with violence, if need be, he can move everything and everyone, so as to lead them from immobility to motion, from ignorance to knowledge, from darkness to light, towards the distant shores of life and death, indeed to the point of reaching the incredible mysteries of life, that is, to make the impossible possible and thereby penetrate the realm of the dead - and even emerge from it.

Thus, not only is Orpheus - since the development of Greek tragedy, one of the first literary genres to refer to him - a model, but also the wise man, the mediator, the musical teacher par excellence. In view of the source and extent of his remarkable qualities and abilities, as well as his exemplary actions and works, he appears to be the guarantor of the right balance and proper evolution of all things against the backdrop of the ceaseless comings and goings of worldly phenomena.

Article Note: Many thanks are due to Andreas Markantonatos for polishing the English translation.

107 On Orpheus' human nature, which is the basis of the Orphic tradition, see Bernabé 2008a, 29. 